Journal of Food Sciences; Suez Canal University, 2018

\title{
Novel Products from Amhat Date
}

\author{
Abo Taleb, Hasnaa M.*; Hanan A. Abd El Aziz; Azza Abd EL Hameed Kamal El Deen \\ Horticulture Crops Technology Research Department, Food Technology Research Institute, Agricultural Research \\ Center, Giza, Egypt
}

Received: $20 / 11 / 2017$

\begin{abstract}
The aim of this study is to introduce new products of fresh Amhat dates, which could be industrials processed and consumed all over the year as the production of dates in Egypt is high while the quantity processed in food industry is very limited. In this investigation, seven main products of Amhat dates were Amhat dates jam (AJ), Amhat dates jam with orange (AJO), Amhat dates spread with tehina (AST), Amat dates spread with tehina and dark chocolate (ASTC), Amhat dates spread with hazelnut (ASH), Amhat dates sweet without cacao powder (AS) and Amhat dates sweet with cacao powder (ASC). Physiochemical and organoleptic characteristics were determined. In addition, identification and quantification of sugars, phenolic, flavonoid compounds, vitamins B group and A, D, E, K were determined by HPLC. The results showed high percentage of total soluble solids in the jam products (AJ and AJO) and high proportion of fat and protein in all spread products and Amhat dates sweet with cacao powder, also, high minerals and antioxidants activity in all processed products. The results obtained by HPLC for Amhat date of all products identified and quantified sugars, phenolic and flavonoids compounds. Sugars fructose, glucose and xylose represented the highest content of sugars, also, pyrogallol, E-vanillic acid, Alpha-coumaric acid, benzoic acid, elegiac acid and chlorogenic acid are the most important and dominate phenolic compounds, moreover hesperidin, acacetin, routine, rosemarinic, and naringin had the highest levels of flavonoid compounds. The group of vitamins B12, B9, B6, $\mathrm{B} 3$ and vitamin $\mathrm{K}$ represented the highest percentage in all products of Amhat dates. The sensory evaluation showed that all products manufactured from Amhat dates were palatable by all panelists, especially product spread Amhat date with tahina and chocolate (ASTS), which it scored the high values given by panelists.
\end{abstract}

Keywords: Amhat dates, products, chemical composition, nutritional value, antioxidants activity.

\section{INTRODUCTION}

Egypt is the largest country production dates in the world, with a production 1.684 .917 tons, planting area of 115610 (fed.) representing $17.7 \%$ of worlds production. The Egyptian dates are divided into three categories (soft, semi -dry and dry dates). Amhat date is one of the most important soft dates in Egypt, which represents about 38262 tons, from planting area of 2164 (fed.) (AACS, 2015). Amhat dates variety is very sensitive to spoilage and is subjected to fermentation in few days after ripening (rutab stage). This means that Amhat dates must be consumed during few days after natural or artificial ripening to rutab stage (Nezam ElDin and Abd El-Hameed, 1997a). Amhat dates were preserved at Khalal stage in sugar solution $(30 \%)$ with different additives (ascorbic acids or lime juice), sterilized in jars and stored for 8 months. The results revealed that treated solution by ascorbic acid showed the best color, taste and flavor during storage and reduce the loss and spoilage of this variety (Nezam El-Din and Abd El-Hamed, 2004).

Date powder was prepared from the khalal stage of Amhat, Siwi and Hayani date varieties and unpollinated Siwi date, the organoleptic evaluation of date powder revealed that color, taste and flavor of khalal date of the previous different varieties mixed with the unpollinated Siwi date were enhanced and acceptable compared to the powder of unpollinated date alone (Nezam El-Din and Abd-El-Hamed, 2003).

Dates fruits rich in carbohydrates (44-88\%), mainly glucose and fructose, protein $2.3-5.6 \%$ and fats $0.2-0.5 \%$, good source of vitamins B complex, dietary fiber, minerals, phenolic, carotenoids and antioxidants (Nasir et al., 2015). Date fruits have bioactive components like carbohydrates, dietary fiber, minerals, some essential vitamins and photochemical such as phenols, sterols, carotenoids, anthocyanins, procyanidins and flavonoids compounds (Baligo et al., 2011).

Radwan et al. (2015) produced high quality products from soft dates (Hayani and Amhat) at rutab stage. They dehydrated the date after deseed and mincing then mixed with some concentrated juices (mango, apricot, guava and strawberry). Sensory evaluation showed that mixing the dates with $20 \%$ fruit juices concentrate were better than $10 \%$, also using the dehydrated dates with ground biscuit and Kamar El- din sheet gave high palatability scores. The present study aimed to produce high quality new products by using new forms for consuming the Amhat dates at rutab stage.

\section{MATERIALS AND METHODS}

\section{Materials}

Amhat dates variety at rutab stage and Orange fruits were obtained from Filed Crops Research Institute, Agricultural Research Center, Giza, Egypt.

Milk powder, sugars, white honey, butter, hazelnut, dark chocolate, cacao powder, dream whip, wheat flour, raisin, coconut, sesame and tahina were purchased from the local market in Giza governorate, Egypt.

All chemicals and reagents used in this study were of analytical grade and purchased from ElGomhouria Co., chemicals used in HPLC methods were of HPLC grade and purchased from (Sigma - Aldrich Co. UK).

\footnotetext{
*Corresponding author e-mail: dr.hasnaa_m@yahoo.com
} 


\section{METHODS}

\section{Preparation of Amhat dates product Preparation of Amhat dates jam}

Fresh Amhat was washed and cleaned by water, decapoded and deseeded and then divided into two parts as follows:

The first: $1000 \mathrm{~g}$ of Amhat dates was mixed with $500 \mathrm{~g}$ sugar, citric acid was added, then the mixture were cooked until final product contained $67.2 \%$ total soluble solids for product Amhat dates jam (AJ).

The second: $800 \mathrm{~g}$ of Amhat date mixed with $500 \mathrm{~g}$ sugar, $125 \mathrm{ml}$ orange juice and $75 \mathrm{~g}$ orange peel, citric acid was added,then the mixture were cooked until final product contained $64.18 \%$ total soluble solids for product Amhat dates jam with orange (AJO). Final jam (AJ and AJO) were kept in sterilized glass jars.

\section{Preparation of Amhat dates spread}

Amhat dates were prepared as the abovementioned treatments, and divided into three parts as follows:

The first: $500 \mathrm{~g}$ of Amhat dates were blended, heated for 5 minutes, then mixed with $50 \mathrm{~g}$ milk powder, $100 \mathrm{~g}$ white honey and $250 \mathrm{~g}$ tahina for produce product Amhat dates spread with tehina (AST).

The second: the previous ingredients were mixed with $200 \mathrm{~g}$ dark chocolate for produce product Amhat dates spread with tahina and dark chocolate (ASTC).

The third: $800 \mathrm{~g}$ Amhat dates mixed with $40 \mathrm{~g}$ sugar, $50 \mathrm{~g}$ butter, $125 \mathrm{~g}$ hazelnut $100 \mathrm{~g}$ dark chocolate, $100 \mathrm{~g}$ cacao powder, $40 \mathrm{~g}$ dream wipe and $50 \mathrm{ml}$ boiled water in blender for produce products Amhat dates spread with hazelnut (ASH).

The obtained final spread (AST, ASTC and ASH) were packed in sterilized glass jars.

\section{Preparation of Amhat dates sweet}

Amhat dates were prepared as the abovementioned treatments, and divided into two parts as follows:

The first: $500 \mathrm{~g}$ of Amhat dates were blended, heated for 10 minutes, $200 \mathrm{~g}$ of butter mixed with $300 \mathrm{~g}$ wheat flours, heated till roasted, in this step add heated Amhat dates mixed and stir till the mixture is smooth for produce products Amhat dates sweet (AS).

The second: the previous ingredients were mixed with $100 \mathrm{~g}$ cacao powder and $50 \mathrm{ml}$ boiled water for produce products Amhat dates sweet with cacao powder (ASC). Finally, Amhat dates sweet (AS and ASC) were formed in suitable shape.

\section{Chemical analysis}

Moisture content, crude protein, fat, total soluble solids (TSS), ash, $\mathrm{pH}$ value and total acidity were determined according to the methods of AOAC (2010). Antioxidant activity was determined by the method of Sheng and Silva (2006).

\section{Determination of minerals}

Minerals (Ca, Mg, Fe, Zn) were measured using Perkin Elmer Atomic Absorption Spectrophotometer (Model 2380, Japan), on the other hand Mn and K were determined using Flame Photometer (model PE P7, England) as described with AOAC (2010).

Identification and quantification of sugars by HPLC

The sugars of fresh Amhat dates and their products were fractionated and identified by HPLC (Hewllet Packared, series 1050 county origin) according to the method of (Chinnici et al., 2005).

Identification and quantification of phenolic and flavonoid compounds by HPLC

Fractionation and identification of phenolic compounds were carried out by HPLC according to the method described by Pascale et al. (1999), while flavonoid compounds were carried out by HPLC according to the method described by Pirjo et al. (2000).

\section{Determination of vitamins}

Vitamins B group were determined by HPLC according to the method of Papadoyannis et al. (1997). Vitamin E and A were determined by HPLC as described by Pyka and Sliwiok (2001). Vitamin K was determined according to Tomas et al. (2007), and vitamin D according to Gfimiz-Gracia et al. (2015).

\section{Sensory evaluation}

All the processed products were organoleptically tested for their color, taste, odor, texture and overall acceptability using a scale from 1 to 10 and the decisions were as follows: excellent (10); Very good (89); Palatable (6-7) and non-palatable (0-5) according to Larmond (1970).

\section{Statistical analysis}

The collected data were recorded as means and analyzed by (SAS) windows (ver.10.1) using one-way (ANOVA) and Duncan comparisons were tested to signify differences between different samples. Value $<$ 0.05 was considered statistically significant. Data were expressed as means, according to (Snedecor and Cochran, 1990).

\section{RESULTS AND DISCUSSIONS}

Physicochemical properties of fresh Amhat dates and its products

Data presented in Table (1) showed the physicochemical composition of fresh Amhat dates and its products, it could be noticed that moisture content was $49.73 \%$ for fresh Amhat dates, while it ranged from 15.57 to $35.31 \%$ for other products. Concerning the protein contents results in Table (1) showed that product AST and ASTC contained high value which being amounted 10.02 and $10.99 \%$, respectively, while products ASH, AS and ASC were recorded 8.25, 5.69 and $5.50 \%$, respectively. For fat content, products AST, ASTC, ASH, AS and ASC had the highest content which ranged from 17.31 to $21.83 \%$.

From Table (1), it could be observed that total soluble solids recorded 67.2 and $64.18 \%$ for AJ and AGO, respectively, while a clear variation was observed between the other products. This variation related to the different ingredients that used in these products. Product $\mathrm{ASH}$ had the highest content of ash (2.71\%) followed 
by product AST and ASTC, while the other products had ash ranging from 0.83 to $1.84 \%$, respectively. $\mathrm{pH}$ value was 6.76 for fresh Amhat dates, while it also ranged from 4.72 to 6.90 for its products, total acidity is nearly constant at $0.2 \%$ in all products except very slight increments, which occurred in few treatments. Regarding the antioxidant activity results in Table (1) showed that antioxidant activity of fresh Amhat dates was $63.3 \%$, while ASC recorded the highest antioxidant activity $(91.8 \%)$ and for the other products, it ranged from 61.3 to $88.7 \%$. Wang et al. (2010), reported that the interaction occurred during heat processed, synergies between antioxidant compounds and the food matrix can occur, in other studies, antioxidant activity remained constant (Leitao et al., 2011) or can be decreased (Davidov et al., 2011).

Table (1): Physicochemical properties of fresh Amhat dates and its different products (on dry weight basis)

\begin{tabular}{|c|c|c|c|c|c|c|c|c|}
\hline \multirow{2}{*}{ Constituents \% } & \multirow{2}{*}{$\begin{array}{l}\text { Fresh Amhat } \\
\text { dates }\end{array}$} & \multicolumn{2}{|c|}{ Jam } & \multicolumn{3}{|c|}{ Amhat dates spread } & \multicolumn{2}{|c|}{ Amhat sweet } \\
\hline & & AJ & AJO & AST & ASTC & ASH & AS & ASC \\
\hline Moisture & 49.73 & 15.57 & 21.04 & 32.74 & 26.82 & 35.31 & 28.37 & 20.14 \\
\hline Protein & 1.5 & 1.3 & 1.4 & 10.02 & 10.99 & 8.25 & 5.69 & 5.50 \\
\hline Fat & 1.3 & 1.1 & 1.02 & 21.83 & 17.31 & 21.59 & 20.59 & 19.04 \\
\hline $\begin{array}{l}\text { Total soluble solids } \\
\text { (TSS) }\end{array}$ & 42.39 & 67.2 & 64.18 & 46.39 & 29.52 & 33.39 & 26.80 & 19.53 \\
\hline Ash & 1.84 & 0.83 & 0.83 & 2.36 & 2.07 & 2.71 & 1.52 & 1.75 \\
\hline pH value & 6.76 & 5.06 & 4.72 & 6.62 & 6.72 & 6.90 & 6.45 & 6.36 \\
\hline $\begin{array}{l}\text { Total acidity } \\
\text { (as citric acid) }\end{array}$ & 0.190 & 0.266 & 0.352 & 0.198 & 0.192 & 0.189 & 0.200 & 0.218 \\
\hline $\begin{array}{l}\text { Antioxidant } \\
\text { activity }\end{array}$ & 63.3 & 88.7 & 79.9 & 70.6 & 75.8 & 61.3 & 76.2 & 91.8 \\
\hline $\begin{array}{l}\text { AJ: Amhat dates jam } \\
\text { AST: Amhat dates sprea } \\
\text { ASH: Amhat dates spre } \\
\text { ASC: Amhat dates swee }\end{array}$ & $\begin{array}{l}\text { vith tehina } \\
\text { with hazelnut } \\
\text { ith cacao powder }\end{array}$ & & $\begin{array}{l}\text { Amhat } \\
\text { C: Amha } \\
\text { Amhat d }\end{array}$ & $\begin{array}{l}\text { s jam wit } \\
\text { te spread } \\
\text { sweet wi }\end{array}$ & $\begin{array}{l}\text { range } \\
\text { h tehina a } \\
\text { ut cacao } p\end{array}$ & $\begin{array}{l}\text { dark choc } \\
\text { der }\end{array}$ & & \\
\hline
\end{tabular}

\section{Nutritional quality of Amhat dates and its produts} Mineral contents

Table (2) showed the composition of elements, potassium $(\mathrm{K})$, magnesium $(\mathrm{Mg})$, calcium $(\mathrm{Ca})$, manganese $(\mathrm{Mn})$, iron $(\mathrm{Fe})$ and zinc $(\mathrm{Zn})$ on dry weight basis. Data in Table (2) showed that product ASC had the highest amounts of K $(692.47 \mathrm{mg} / 100 \mathrm{~g})$ followed by product AS (387.35 mg/100g), fresh Amhat (370.12 $\mathrm{mg} / 100 \mathrm{~g}$ ) while the lowest was record in product AJO (108.80 mg/100g).

Table (2): Mineral contents of fresh Amhat dates and its products (on dry weight basis)

\begin{tabular}{|c|c|c|c|c|c|c|c|c|}
\hline \multirow{2}{*}{ Minerals (mg/100g) } & \multirow{2}{*}{$\begin{array}{c}\text { Fresh Amhat } \\
\text { dates }\end{array}$} & \multicolumn{2}{|c|}{ Jam } & \multicolumn{3}{|c|}{ Amhat dates spread } & \multicolumn{2}{|c|}{ Amhat sweet } \\
\hline & & $\mathbf{A J}$ & AJO & AST & ASTC & ASH & $\mathbf{A S}$ & ASC \\
\hline Potassium (K) & 370.12 & 176.40 & 108.80 & 174.07 & 312.28 & 335.35 & 387.35 & 692.47 \\
\hline Magnesium (Mg) & 91.756 & 158.022 & 104.273 & 228.58 & 227.79 & 181.82 & 92.212 & 120.49 \\
\hline Calcium (Ca) & 157.56 & 223.08 & 143.32 & 226.63 & 255.07 & 181.82 & 40.262 & 59.450 \\
\hline Manganese (Mn) & 0.70 & 0.708 & 0.773 & 0.252 & 0.299 & 0.499 & 0.156 & 0.364 \\
\hline Iron ( Fe) & 0.721 & 0.319 & 0.201 & 1.007 & 0.749 & 2.496 & 1.286 & 2.682 \\
\hline Zinc (Zn) & 0.309 & 0.342 & 0.371 & 0.951 & 1.048 & 0.535 & 0.519 & 0.754 \\
\hline $\begin{array}{l}\text { AJ: Amhat dates jam } \\
\text { AST: Amhat dates sprea } \\
\text { ASH: Amhat dates sprea } \\
\text { ASC: Amhat dates swee }\end{array}$ & $\begin{array}{l}\text { with tehina } \\
\text { with hazelnut } \\
\text { with cacao pow }\end{array}$ & & $\begin{array}{l}\text { AJO: Am } \\
\text { ASTC: A } \\
\text { AS: Amh }\end{array}$ & $\begin{array}{l}t \text { dates jar } \\
\text { hat date sp } \\
\text { dates swe }\end{array}$ & $\begin{array}{l}\text { with orang } \\
\text { ad with tel } \\
\text { without ce }\end{array}$ & $\begin{array}{l}\text { a and dark } \\
\text { o powder }\end{array}$ & tocolate & \\
\hline
\end{tabular}


Data in Table (2) showed that product ASTC appear to be rich in calcium (255.07), zinc (1.048) and contain considerable amount of magnesium (227.79 $\mathrm{mg} / 100 \mathrm{~g}$ ). As for iron content, products ASC, ASH and AS had the highest content. On the other hand, (Mn) ranged from 0.156 to $0.773 \mathrm{mg} / 100 \mathrm{~g}$ for different products. The previous results appeared clear differences between all products in the amounts of minerals, this may be related to ingredients additive. Shaba et al. (2015) found that dates fruits contain from $\mathrm{Ca}, \mathrm{Mg}, \mathrm{K}, \mathrm{Zn}$ and Fe were 79.62, 66.33, 55.11, 0.86 and $4.56 \mathrm{mg} / 100 \mathrm{~g}$, respectively. On the other hand, the element analysis of date palm extract showed that, the fruit of date palm contains many of valuable and useful elements like calcium, potassium, magnesium and iron in percentages $65,521,20$ and $2.69 \%$, respectively, ElSohaimy and Hafez (2010). Youssef et al. (1999) determined both macro and micro-elements in some new valley dates and certain dates products, they found that potassium content recorded the highest levels in all varieties, the rutab stage of Saldy dates had gave lesser $\mathrm{K}, \mathrm{Na}$, and $\mathrm{Fe}$ contents than Balady and Manthour dates, but it was intermediate between them in $\mathrm{Ca}, \mathrm{Mg}$ and $\mathrm{Mn}$, also the treated and packed saldy dates products differed in minerals content, the date paste followed by pressed dates (Agwa) recorded the highest iron content.
Identification and quantification of sugars contents of fresh Amhat dates and its products

In fresh Amhat dates a large portion of soluble solid is sugars, from Table (3) it could be seen that fresh Amhat dates had the highest amount of fructose, glucose, mannose and galactose $(41.45,32.32,17.68$ and $17.03 \%$, respectively), while sucrose recorded low amounts $(0.189 \%)$. HPLC analysis of sugars content showed that, the carbohydrate content consists of a large amount of glucose, fructose and sucrose (El-Sohaimy and Hafez, 2010).

Muhammad et al. (2014) reported that sucrose converts to reducing sugars especially glucose and fructose with no or very low sucrose. Product AJ and AJO recorded the same value of sucrose (22.18\%). As for arabinose product AJO had the highest content than other ones, while maltose content was high in product $\mathrm{AJ}$ and AJO as well as xylose had the highest content in product AJ (21.62\%) when compared to other products. Other sugars were identified as shown in Table (3) that recorded different low concentration in fresh Amhat dates and its products. The variation between identified sugars of fresh Amhat dates and its processed products may be related to that different ingredients, were used in processing these products.

Table (3): Identification and quantification of sugars contents of fresh Amhat dates and its products (on dry weight basis)

\begin{tabular}{|c|c|c|c|c|c|c|c|c|}
\hline \multirow{2}{*}{$\begin{array}{l}\text { Sugars } \\
\text { compounds } \\
(\mathrm{g} / \mathbf{1 0 0 g})\end{array}$} & \multirow{2}{*}{$\begin{array}{c}\text { Fresh Amhat } \\
\text { dates }\end{array}$} & \multicolumn{2}{|c|}{ Jam } & \multicolumn{3}{|c|}{ Amhat dates spread } & \multicolumn{2}{|c|}{ Amhat sweet } \\
\hline & & AJ & AJO & AST & ASTC & ASH & AS & ASC \\
\hline Glucuronic & 0.370 & 0.323 & 0.190 & 2.676 & 0.157 & 0.122 & 0.166 & 0.990 \\
\hline Stackhouse & 0.648 & 0.206 & 0.305 & 0.497 & 0.303 & 0.195 & 0.195 & 0.144 \\
\hline Galacturonic & 0.442 & 0.769 & 1.077 & 1.867 & 1.058 & 0.424 & 0.240 & 0.144 \\
\hline Sucrose & 0.189 & 22.18 & 22.18 & 2.449 & 4.813 & 1.639 & 0.747 & 2.208 \\
\hline Maltose & 0.149 & 23.61 & 23.62 & 2.608 & 5.124 & 1.744 & 0.796 & 2.350 \\
\hline Glucose & 32.32 & 18.53 & 21.69 & 11.34 & 10.26 & 9.753 & 11.90 & 6.836 \\
\hline Xylose & 21.62 & 14.33 & 17.12 & 8.929 & 7.539 & 7.889 & 8.912 & 5.746 \\
\hline Galactose & 17.03 & 0.352 & 13.49 & 0.134 & 0.094 & 6.214 & 10.36 & 0.056 \\
\hline Mannose & 17.68 & 0.366 & 14.01 & 0.139 & 0.098 & 0.063 & 0.103 & 0.059 \\
\hline Arabinose & 4.874 & 29.09 & 34.49 & 2.046 & 18.20 & 17.36 & 19.28 & 11.51 \\
\hline Fructose & 41.45 & 24.74 & 29.33 & 17.40 & 15.48 & 14.76 & 16.39 & 9.807 \\
\hline Mannitol & 0.662 & 0.045 & 0.013 & 2.046 & 1.069 & 0.079 & 0.099 & 0.086 \\
\hline Sorbitol & 1.623 & 0.595 & 0.505 & 0.375 & 0.295 & 0.275 & 0.346 & 0.341 \\
\hline
\end{tabular}

AJ: Amhat dates jam

AST: Amhat dates spread with tehina

ASH: Amhat dates spread with hazelnut

ASC: Amhat dates sweet with cacao powder
AJO: Amhat dates jam with orange

ASTC: Amhat date spread with tehina and dark chocolate

AS: Amhat dates sweet without cacao powder 
Identification and quantification of phenolic compounds by HPLC

The results in Table (4) showed that the identification and quantification of 23 phenolic compounds in fresh Amhat dates and all processed products as $(\mathrm{mg} / 100 \mathrm{~g} \mathrm{dw})$. The highest content of pyrogallol was $83.53 \mathrm{mg} / 100 \mathrm{gm}$ for fresh Amhat dates, followed by product AJ $(75.07 \mathrm{mg} / 100 \mathrm{gm})$, product AJO (14.45 mg/100gm) product ASH (12.22 $\mathrm{mg} / 100 \mathrm{gm})$ and product AS (11.62 mg/100gm), respectively.
Product ASC had high concentration of catechol $(18.001 \mathrm{mg} / 100 \mathrm{~g})$, while product AJ had moderate content of catechol $(5.157 \mathrm{mg} / 100 \mathrm{~g})$ and the lowest concentration found in product AS $(1.216 \mathrm{mg} / 100 \mathrm{~g})$. The highest content of elegiac acid was 14.86 $\mathrm{mg} / 100 \mathrm{gm}$ for product AST while e-vinylic recorded the highest content in product ASH (158.mg/100gm) followed by fresh Amhat dates (50.68 mg/100gm) ,product AS (27.99 mg/100gm), product AJ (26.89 $\mathrm{mg} / 100 \mathrm{gm})$, product ASTC $(21.02 \mathrm{mg} / 100 \mathrm{gm})$ and $\operatorname{AST}(18.74 \mathrm{mg} / 100 \mathrm{gm})$, respectively.

Table (4): Identification and quantification of phenolic compounds by HPLC of fresh Amhat dates and its products (on dry weight basis)

\begin{tabular}{|c|c|c|c|c|c|c|c|c|}
\hline \multirow{2}{*}{$\begin{array}{l}\text { Phenolic compounds } \\
\text { (mg/100gm) }\end{array}$} & \multirow{2}{*}{$\begin{array}{l}\text { Fresh Amhat } \\
\text { dates }\end{array}$} & \multicolumn{2}{|c|}{ Jam } & \multicolumn{3}{|c|}{ Amhat dates spread } & \multicolumn{2}{|c|}{ Amhat sweet } \\
\hline & & AJ & AJO & AST & ASTC & ASH & $\mathbf{A S}$ & ASC \\
\hline Gallic acid & 5.872 & 7.822 & 1.906 & 0.553 & 0.229 & 0.257 & 0.796 & 0.686 \\
\hline Pyrogallol & 83.53 & 75.07 & 14.45 & 4.844 & 7.334 & 12.22 & 11.62 & 9.32 \\
\hline 4-Amino-benzoic acid & 0.296 & 0.506 & 0.319 & 0.120 & 0.134 & 0.130 & 0.092 & 0.192 \\
\hline Protocatechuic acid & 3.044 & 0.625 & 1.053 & 1.935 & 1.276 & 1.345 & 1.009 & 1.121 \\
\hline Catechin & 2.629 & 1.300 & 0.885 & 1.164 & 1.382 & 1.820 & 1.276 & 0.394 \\
\hline Chlorogenic acid & 4.076 & 3.013 & 1.092 & - & 1.279 & 1.047 & 0.931 & 1.022 \\
\hline Chatechol & 3.211 & 5.157 & 2.869 & 2.993 & 3.375 & 4.178 & 1.216 & 18.001 \\
\hline Epi-catechin & 1.318 & 0.791 & 0.666 & 0.844 & 0.655 & - & 0.494 & 1.038 \\
\hline Caffeine & 0.315 & 0.313 & 0.194 & 1.701 & 5.254 & 0.939 & 0.593 & 0.781 \\
\hline$\rho-O H-b e n z o i c ~ a c i d ~$ & 1.394 & 0.332 & 1.843 & 1.803 & - & 0.997 & 0.306 & 0.636 \\
\hline Caffpeic acid & 0.710 & 0.327 & 0.338 & 0.128 & 0.123 & 0.319 & 0.110 & 0.202 \\
\hline Vanillic acid & 3.616 & 1.666 & 1.724 & 0.649 & 1.623 & 1.643 & 0.564 & 1.019 \\
\hline$\rho$-Coumaric acid & 1.189 & 0.612 & 0.585 & 0.583 & 0.674 & - & 0.268 & 0.272 \\
\hline Ferulic acid & 5.719 & 0.354 & 0.507 & 0.384 & 1.848 & - & 0.573 & 0.235 \\
\hline Iso-Ferulic acid & 0.448 & 0.019 & 0.057 & 0.165 & 0.120 & 1.404 & 0.247 & 0.050 \\
\hline Ellagic acid & 6.075 & 3.077 & 4.349 & 14.86 & 3.368 & 8.490 & 6.721 & 8.242 \\
\hline e-Vinillic acid & 50.68 & 26.89 & 6.506 & 18.74 & 21.02 & 158.7 & 27.99 & 5.665 \\
\hline Alpha-Coumaric acid & 3.427 & 88.61 & 10.60 & 22.68 & 12.19 & 2.359 & 3.280 & 1.528 \\
\hline Benzoic acid & 5.319 & 8.105 & 11.71 & 39.44 & 8.938 & 35.11 & 17.84 & 21.89 \\
\hline 3,4,5-methoxy-cinnamic acid & 1.338 & 0.854 & 0.866 & - & - & 0.804 & 0.475 & 0.172 \\
\hline Coumarin & 0.907 & 0.361 & 0.862 & 0.422 & 0.267 & 0.113 & 0.126 & 0.094 \\
\hline Salicylic acid & 2.403 & 0.385 & 0.604 & 1.285 & 0.962 & 0.745 & 0.249 & 0.187 \\
\hline Cinnamic acid & 0.207 & 0.025 & 0.027 & 0.039 & 0.061 & 0.201 & 0.029 & 0.018 \\
\hline
\end{tabular}

AJ: Amhat dates jam

AST: Amhat dates spread with tehina

ASH: Amhat dates spread with hazelnut

ASC: Amhat dates sweet with cacao powder
AJO: Amhat dates jam with orange

ASTC: Amhat date spread with tehina and dark chocolate AS: Amhat dates sweet without cacao powder 
From the same Table (4) it was noticed that the highest content of alpha-coumaric was $88.61 \mathrm{mg} / 100 \mathrm{gm}$ for product AJ followed by products AST (22.68 $\mathrm{mg} / 100 \mathrm{gm})$, and product ASTC (12.19 mg/100gm), also product AST and ASH had the highest amounted benzoic acid than other ones. On the other hand, the other phenolic compounds of fresh Amhat dates and all processed products recorded a moderate and little concentration between them as shown in Table (4). The variation between all phenolic compounds of processed products may be related to the different ingredients, which used in processing these products.

Our results are in agreement with Al-Farsi et al. (2005) who found that date fruits are an excellent source of phenolic and therefore possess an extremely high antioxidant capacit. Date fruits have been reported to contain various phenolics, such as protocaechuic, $\rho$ hydroxybenzoic, vanillic, syringic, caffeic, coumaric, ferulic, hydroxyl benzoic, hydroxyl cinnamic acids, which contribute significantly to total antioxidant. Ghnimi et al. (2017), also found that Phenolic classes of and identified compounds in date fruits were benzoic acids and derivatives (gallic acid, protocatechuic acid, $p$-hydroxybenzoic acid, vanillic acid, synaptic acid, and syringe acid) and Cinnamic acid and derivatives (caffeic acid, hydrocaffeic acid, ferulic acid, $p$-coumaric acid, syringic acid, dactyliferic acid, 2 caffeoylshikimic acid hexosides, 3-caffeoylshikimic acid, 4-caffeoylshikimic acid, 5-caffeoylshikimic acid, caffeoylsinapoyl hexoside, and dicaffeoylsinapoyl hexoside), while (Hamad et al., 2015) found that the major phenolic acids in Saudi date fruit varieties were gallic acid, $p$-coumaric acid, and ferulic acid.

\section{Identification and quantification of flavonoid compounds}

The results in Table (5) revealed that the hesperidin was the dominant flavonoid component in fresh Amhat dates and its products which recorded high value in product AJO (45.92 $\mathrm{mg} / 100 \mathrm{gm})$ followed by fresh Amhat dates $(22.09 \mathrm{mg} / 100 \mathrm{gm})$, product AJ $(16.98 \mathrm{mg} / 100 \mathrm{gm})$ and other products ranged from 3.466 to $14.28 \mathrm{mg} / 100 \mathrm{gm}$. Rosmarinic was the major flavonoid in product AST $(18.79 \mathrm{mg} / 100 \mathrm{gm})$ followed by product AJO $(16.09 \mathrm{mg} / 100 \mathrm{gm})$, product ASC $(12.63 \mathrm{mg} / 100 \mathrm{gm})$ and product ASH (10.66 $\mathrm{mg} / 100 \mathrm{gm})$. The investigation revealed that the highest level of flavonoid hesperidin, acacetin and quercitrin were $45.92,14.62$ and $1.939 \mathrm{mg} / 100 \mathrm{gm}$, respectively. On the other hand, product ASTC had maximum content from naringin $(9.453 \mathrm{mg} / 100 \mathrm{gm})$.

Table (5): Identification and quantification of flavonoid compounds by HPLC of fresh Amhat dates and its products (on dry weight basis)

\begin{tabular}{|c|c|c|c|c|c|c|c|c|}
\hline \multirow{2}{*}{$\begin{array}{l}\text { Flavonoid } \\
\text { compounds } \\
\text { (mg /100g) }\end{array}$} & \multirow{2}{*}{$\begin{array}{c}\text { Fresh Amhat } \\
\text { dates }\end{array}$} & \multicolumn{2}{|c|}{ Jam } & \multicolumn{3}{|c|}{ Amhat dates spread } & \multicolumn{2}{|c|}{ Amhat sweet } \\
\hline & & AJ & AJO & AST & ASTC & ASH & AS & ASC \\
\hline Naringin & 1.247 & 1.143 & 1.563 & 4.364 & 9.453 & 3.273 & 1.323 & - \\
\hline Rutin & 4.382 & 3.367 & 2.258 & 2.229 & 2.544 & 2.832 & 1.289 & 1.852 \\
\hline Hesperidin & 22.09 & 16.98 & 45.92 & 11.24 & 12.83 & 14.28 & 6.499 & 3.466 \\
\hline Rosmarinic & - & 3.816 & 16.09 & 18.79 & - & 10.66 & 5.104 & 12.63 \\
\hline Quercitrin & 1.991 & 1.053 & 1.939 & 1.841 & 0.573 & 1.749 & 0.891 & 1.883 \\
\hline Quercetin & 0.509 & - & 0.403 & - & 0.167 & 0.249 & - & 0.076 \\
\hline Hispertin & 0.865 & 0.891 & 1.198 & - & 0.225 & 0.570 & - & 0.202 \\
\hline Kaempferol & 0.107 & 0.109 & 0.086 & - & 0.167 & 0.165 & 0.022 & 0.149 \\
\hline Rhamnetin & 0.103 & 0.065 & 0.141 & 0.054 & 0.023 & 0.136 & 0.017 & 0.034 \\
\hline Apigenin & 0.913 & 3.219 & 2.633 & 0.572 & 0.509 & 0.860 & 0.910 & 0.473 \\
\hline Acacetin & 10.82 & 4.425 & 14.62 & 3.091 & 0.970 & 4.789 & 0.730 & 3.381 \\
\hline $\begin{array}{l}\text { AJ: Amha } \\
\text { AST: Amha } \\
\text { ASH: Amha } \\
\text { ASC: Amha }\end{array}$ & $\begin{array}{l}\text { with tehina } \\
\text { with hazelnut } \\
\text { with cacao pow }\end{array}$ & & $\begin{array}{l}\text { JO: Am } \\
\text { STC: Ar } \\
\text { IS: Amh }\end{array}$ & $\begin{array}{l}\text { lates jam } \\
\text { date spre } \\
\text { tes sweet }\end{array}$ & $\begin{array}{l}\text { h orange } \\
\text { with tehin } \\
\text { hout caca }\end{array}$ & $\begin{array}{l}\text { Ind dark } \\
\text { owder }\end{array}$ & colate & \\
\hline
\end{tabular}

The other identified flavonoids showed a little change in the content values, the variation between all flavonoid compounds of processed products might be related to the variation in the ingredients used in processing these products. Our result are in agreement with Ghnim el al. (2017), who found that identified of Flavonoid glycosides and esters compounds in date fruits were Luteolin, quercetin and apigenin, quercetin rhamnosyl-hexoside sulfate, quercetin 3-O-rutinoside (rutin), quercetin hexoside sulfate, quercetin acetyl- 
hexoside, isorhamnetin-3-O-rutinoside, isorhamnetin hexoside, chrysoeriol rhamnosyl-hexoside, isorhamnetin acetyl-hexoside, quercetin 3-O-glucoside (isoquercitrin), chrysoeriol hexoside sulfate, and chrysoeriol hexoside.

Lin and Weng (2006), Khan et al. (2010), reported that the flavonoids have cardio protective, antioxidant, anti-inflammatory, anti-cancer and antimicrobial properties, and are one of the most potent nutraceuticals in food and phytopharmaceutical products. Therefore, it is paramount to understand the principles of biological activity, bioavailability and metabolism of Amhat dates flavonoids in relation to human health.
Vitamins B group contents and vitamins A, D, E, K of fresh Amhat dates and its products

Some vitamins B (B1, B2, B3, B6, B9 and B12), also vitamins $\mathrm{A}, \mathrm{D}, \mathrm{E}$, and $\mathrm{K}$ levels of fresh Amhat dates and its products are presented in Table (6). Fresh Amhat dates had the highest level of vitamins B2, B3, B6, B9 and B12. Also it showed that the processing of Amhat dates caused a decrease in those vitamins, the results also revealed that fresh Amhat dates contain low amounts of vitamin B1.

Table (6): Vitamins B group contents and vitamins A, D, E, K, of fresh Amhat dates and its products (on dry weight basis)

\begin{tabular}{|c|c|c|c|c|c|c|c|c|c|}
\hline \multirow{2}{*}{\multicolumn{2}{|c|}{ Vitamins (mg /100g) }} & \multirow{2}{*}{$\begin{array}{c}\text { Fresh Amhat } \\
\text { dates }\end{array}$} & \multicolumn{2}{|c|}{ Jam } & \multicolumn{3}{|c|}{ Amhat dates spread } & \multicolumn{2}{|c|}{ Amhat sweet } \\
\hline & & & AJ & AJO & AST & ASTC & ASH & $\mathbf{A S}$ & ASC \\
\hline \multirow{6}{*}{$\begin{array}{l}\text { Vit. B } \\
\text { group }\end{array}$} & Thiamine (B1) & 0.893 & 0.798 & 0.747 & 0.640 & 0.653 & 0.691 & 0.799 & 0.785 \\
\hline & Riboflavin (B2) & 4.663 & 1.983 & 0.893 & 2.055 & 1.454 & 2.874 & 1.664 & 0.970 \\
\hline & Nicotinic (B3) & 11.280 & 2.668 & 2.587 & 0.309 & 3.149 & 3.848 & 1.692 & 2.365 \\
\hline & Pyridoxine (B6) & 4.360 & 3.251 & 3.894 & 4.085 & 4.169 & 4.009 & 4.205 & 3.995 \\
\hline & Folic acid (B9) & 11.270 & 3.769 & 1.145 & 3.085 & 3.013 & 4.603 & 6.345 & 6.888 \\
\hline & Cobalamin (B12) & 32.520 & 5.839 & 10.510 & 13.590 & 11.390 & 12.070 & 7.905 & 15.040 \\
\hline Vit. A & & 0.312 & 0.384 & 0.404 & 0.191 & 0.035 & 0.047 & 0.002 & 0.233 \\
\hline Vit. D & & 0.285 & 0.196 & 0.201 & 0.149 & 0.059 & 0.082 & 0.029 & 0.023 \\
\hline Vit. E & & 0.024 & 0.055 & 0.012 & 0.033 & 0.005 & 0.019 & 0.009 & 0.254 \\
\hline Vit. K & & 98.880 & 7.318 & 6.686 & 14.340 & 18.830 & 13.640 & 24.620 & 28.240 \\
\hline
\end{tabular}

AJ: Amhat dates jam

AST: Amhat dates spread with tehina

ASH: Amhat dates spread with hazelnut

ASC: Amhat dates sweet with cacao powder

The reduction in vitamins $B$ groups that would be due to different processing of fresh Amhat date, in the present study is agreement with Fadahunsi (2009), who found a clear different decrease in vitamins B group when study the effect of treatment conditions (soaking, boiling and fermentation with Rhizopus oligosporus (SBF) on the water soluble vitamins.

A clear variation was noticed in the amounts of vitamin A, D and E between fresh Amhat dates and its products, on other hand vitamin $\mathrm{K}$ recorded a high level $(98.88 \mathrm{mg} / 100 \mathrm{~g})$ in fresh Amhat dates that was decreased after treating and processing. El-Sohaimy and Hafez (2010) reported that the palm fruit contains many kinds of vitamins like, A, B1, B2 and Nicotinic acid
AJO: Amhat dates jam with orange

ASTC: Amhat date spread with tehina and dark chocolate

AS: Amhat dates sweet without cacao powder with concentrations $0.04,0.08,0.05$ and $2.20 \mathrm{mg} / 100 \mathrm{~g}$, respectively.

\section{Sensory evaluation of Amhat date products}

The organoleptic evaluation is generally the final guide of quality from the consumers point of view (Jimenez et al., 1989). Results showed that all the Amhat dates products were accepted by the panelists, the description of the overall palatability by the panelists ranged between very good and palatable for all Amhat dates products, it could be noticed that product ASTC had the highest score for all sensory parameters compared with the others, while product AS had the lowest mean value, finely a slight variation, was observed in all processed products. 
Table (7): Sensory evaluation of Amhat dates products

\begin{tabular}{|c|c|c|c|c|c|c|}
\hline \multicolumn{2}{|c|}{ Products No. } & $\begin{array}{l}\text { Color } \\
(10)\end{array}$ & $\begin{array}{l}\text { Taste } \\
(10)\end{array}$ & $\begin{array}{l}\text { Odor } \\
(10)\end{array}$ & $\begin{array}{c}\text { Texture } \\
\text { (10) }\end{array}$ & $\begin{array}{c}\text { Overall } \\
\text { Palatability (10) }\end{array}$ \\
\hline \multirow{3}{*}{ Jam } & AJ & $7.5^{\mathrm{ab}}$ & $7.6^{\mathrm{ab}}$ & $7.7^{\mathrm{a}}$ & $7.3^{\mathrm{ab}}$ & $7.6^{\mathrm{ab}}$ \\
\hline & AJO & $7.5^{\mathrm{ab}}$ & $7.2^{\mathrm{ab}}$ & $7.8^{\mathrm{a}}$ & $7.1^{\mathrm{ab}}$ & $7.5^{\mathrm{ab}}$ \\
\hline & AST & $7.5^{\mathrm{ab}}$ & $6.9^{\mathrm{b}}$ & $7.3^{\mathrm{a}}$ & $8.15^{\mathrm{a}}$ & $7.5^{\mathrm{ab}}$ \\
\hline \multirow{2}{*}{$\begin{array}{l}\text { Amhat } \\
\text { dates } \\
\text { spread }\end{array}$} & ASTC & $8.3^{\mathrm{a}}$ & $8.4^{\mathrm{a}}$ & $7.9^{\mathrm{a}}$ & $8.3^{\mathrm{a}}$ & $8.4^{\mathrm{a}}$ \\
\hline & ASH & $7.8^{\mathrm{ab}}$ & $7.6^{\mathrm{ab}}$ & $7.5^{\mathrm{a}}$ & $8 .^{1 \mathrm{a}}$ & $7.6^{\mathrm{ab}}$ \\
\hline \multirow{2}{*}{$\begin{array}{l}\text { Amhat } \\
\text { sweet }\end{array}$} & AS & $6.6^{\mathrm{b}}$ & $6.5^{\mathrm{b}}$ & $6.9^{\mathrm{a}}$ & $6.8^{\mathrm{b}}$ & $7.2 b$ \\
\hline & ASC & $7.2^{\mathrm{ab}}$ & $7.1^{\mathrm{b}}$ & $7.4^{\mathrm{a}}$ & $6.9^{\mathrm{b}}$ & $7.4^{\mathrm{b}}$ \\
\hline \multicolumn{2}{|c|}{ L.S.D at 0.05} & 0.8626 & 0.9240 & 0.9613 & 0.8732 & 0.6575 \\
\hline
\end{tabular}

Values with different letters in the same column are significantly different at $\mathrm{P}<0.05$

AJ: Amhat dates jam

AST: Amhat dates spread with tehina

ASH: Amhat dates spread with hazelnut

ASC: Amhat dates sweet with cacao powder

\section{CONCLUSION}

The present study provides data for providing the use of Amhat dates as the source of natural compound, bioactive component and antioxidant content. Seven products were produced for lowering the loss of Amhat dates. According to the results, products of jam, spread, and Amhat dates sweet contained different percentage of nutritional and bioactive compounds factors.

\section{REFERENCES}

AACS (2015). Administration Center of Agricultural Economics and Statistics, Ministry of Agriculture, Egypt.

Al-Farsi, M., C. Alasalvar, A. Morris, M. Baron and F. Shahidi (2005). Comparison of antioxidant activity, anthocyanins, carotenoids and phenolic of three native fresh and sundried date (Phoenix dactylifera L.) varieties grown in Oman, J. Agric. Food Chem., 53: 7592 - 7599.

AOAC (2010). Association of Official Analytical Chemists international. Official Methods of Analysis, $19^{\text {th }}$ ed. Washington, D C, U S A.

Baligo, M. S., B. R. Baligo, S. M. Kandathil, H. P. Bhat and P. K. Vayalil (2011). A review of the chemistry and pharmacology of the date fruits (Phoenix dectyilfera L). Food Res. Int., 44: 1812-1834.

Chinnici, F., U. Spinabelli, C. Riponi and A. Amati (2005). Optimization of the determination of organic acids and sugars in fruit juices by ionexclusion liquid chromatography. Journal of Food Composition and Analysis, 18: 121-130.
Davidov, P., M. R. Arozarena and M. Arroyo (2011). Stability of polyphenolic extracts from grape seeds after thermal treatments. Eur. Food Res. Technol., 232: 211-220.

El-Sohaimy, S. and E. Hafez (2010). Biochemical and maturational characterizations of date palm fruits (Phoenix dactylifera L.). Journal of applied sciences research, 6(8):1060-1067.

Fadahunsi, I. F. (2009) .The effect of soaking, boiling and fermentation with Rhizopus oligosporus on the water-soluble vitamin content of Bambara groundnut Pak. J. Nutr., 8: 835-840.

Gfimiz-Gracia, M. M., M. D. Jim6nez-Carmona and C. Luque de (2015). Determination of vitamins D2 and D3 in pharmaceuticals by supercritical-fluid extraction and HPLC separation with UV detection chromatographic. Analytical Chemistry Division, Faculty of Sciences, University of Cdrdoba, 14004 Cdrdoba, Spain, 51(7/8): 428-432.

Ghnimi, S., S. Umer, A. Karim and A. Kamal Eldin (2017). Date fruit (Phoenix dactylifera L.): An underutilized food seeking industrial valorization. NFS Journal, 6: 1-10.

Hamad, I., H. Abd El gawad, S. Al Jaouni, G. Zinta, H. Asard and S. Hassan (2015). Metabolic analysis of various date palm fruit (Phoenix dactylifera L.) cultivars from Saudi Arabia to assess their nutritional quality. Molecules, (20): 13620-13641.

Jimenez, L., J. L. Ferrer and L. M. Paniego (1989). Rheology, composition and sensory properties of pulped tomatoes. Journal of Engineering, 9(2): 119-128. 
Khan, N., V. M. Adhami and H. Mukhtar (2010). Apoptosis by dietary agent for prevention and treatment of prostate cancer. Endocrine-Related Cancer, 17: 39-52.

Larmond, E. (1970). Method of sensory Evaluation of Food. Publ. No. 1974 Can. Department of Agriculture. Laurenzo, Kathleen, S.; Navia, juan, L.; Neiditch and S. David. Preparation of inulin products US., 5: 968-365.

Leitao, C., E. Marchioni, M. Bergaentzlé, M. Zhao, L. Didierjean, B. Taidi and S. Ennahar (2011). Effect of processing steps on the phenolic content and antioxidant activity of bee J. Agric. Food Chem., 59: 1249-1255.

Lin, J. K. and M. S. Weng (2006). Flavonoids as nutraceuticals. In: The Science of Favonoids; Grotewold, E., Ed.; Springer: Berlin, Germany, pp: 213-238.

Muhammad, S., S. M. Aleid and A. A. Kader (2014). Dates. Postharvest science, processing, technology and health benefits. Wiley Blackwell .Department of Food Science and Human Nutrition, Michigan, State University, East Lansing, USA.

Nasir, M. U., S. Hussain, S. Jabbars, F. Rashid, N. Khalid and A. Mahmood (2015). A review on the exertional content functional properties and medicinal potential \& dates. Science letters, 3(1): 17-22.

Nezam El-Din, A. M. M. and K. Abd El Hameed Azza (1997a). Chemical and technological study on Egyptian Amhat date. 1-Effect of temperature on ripening of Khalal date. Egypt J. Agric. Res., 75(4): 1113-1121.

Nezam EL-Din, A. M. M. and K. Abd El Hameed Azza (2003). Production of Khalal date powder. Proceeding of the international conference on date palm. Kingdom of Saudi Arabia- Ministry of Higher Education- King Saud UniversityQaseem Branch- college of Agric. and vet. Med. 16-19 September, 87-101.

Nezam El-Din, A. M. M. and K. Abd El-Hameed Azza (2004). Preservation of Khalal dates. 1. Amhat date variety (Soft date). Egypt. J. App. Sci., 19 (12 A): 242-250.

Pascale, G., H. Mireille, B. Patrick and J. Marie (1999). Antioxidant composition and activity of barley (Hordeum vulgare) and malt extracts of isolated phenolic compounds. Journal of the Science of Food and Agriculture, 79: 1625 - 1634.

Papadoyannis, I. N., G. K. Tsioni and V. F. Samanidou (1997). Simultaneous determination of nine water and fat-soluble vitamins after SPE separation and RP-HPLC analysis in pharmaceutical preparations and biological fluids. Journal of liquid Chromatography and Related Technologies, 20: 3203-3231.

Pirjo, M. A. Jouni and K. Jorma (2000). Determination of flavonoids in plant material by HPLC with diode-array and electro-array detections. Journal of Agricultural and Food Chemistry, 48: 58345841 .

Pyke, A. and J. Sliwiok (2001). Chromatographic separation of tocopherols. Journal of Chromatography A, 935: 71-76.

Radwan, H. M., E. Rizk Ayat and A. Hareedy Lobna (2015). Production of high quality products by simple technique from soft dates (Hayani and Amhat) at rutab stage. Egypt. J. Agric. Res. 93(4 C): $999-1011$.

Snedecor, G. W. and W. G. Cochran (1990). Statistical Methods. $11^{\text {th }}$ Ed. Iowa State Univ., Press. Ames, Iowa, USA.

Sheng, S. M. N. and J. L. Silva (2006). Antioxidant activity, anthocyanins and phenolics of rabbiteye blueberry (Vaccinium ashei) byproducts as affected by fermentation. Food Chemistry, 97(3): 447-451.

Shaba E. Y., M. M. Ndamitso, J. T. Mathew, M. B. Etsunyakpa, A. N. Tsado and S. S. Muhammad (2015). Nutritional and anti-nutritional composition of date palm (Phoenix dactylifera L.) fruits sold in major markets of Minna Niger State, Nigeria. African Journal of Pure and Applied Chemistry, 9 (8): 167-174.

Tomas, P. R., M. I. Carmen, G. Ma Dolores and M. Jesus (2007). High-performance liquid chromatography-photochemical reduction in aerobic conditions for determination of $\mathrm{K}$ vitamins using fluorescence detection Journal of Chromatography A, 1141: 67- 72.

Wang, K. A., M. F. Meckling, Y. Marcone and R. Tsao Kakuda (2010) Synergistic, additive, and antagonistic effects of food mixtures on total antioxidant capacities. J. Agric. Food Chem., 59: 960-968.

Youssef, M. K. E., M. N. El-Rify, M. A. H. ElGeddawy and B. R. Ramadan (1999). Nutrient elements and vitamins content of some new valley dates and certain date products. The international conference on Date palm, 9-11 November, Assuit University for Environmental Studies, Egypt. 


\section{منتجات جديدة من بلح الأمهات}

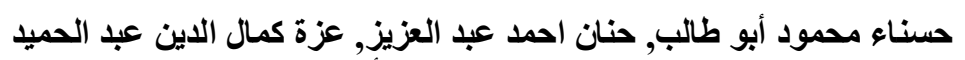

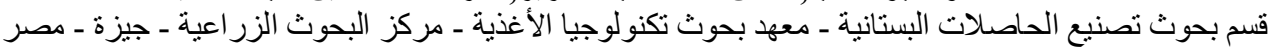

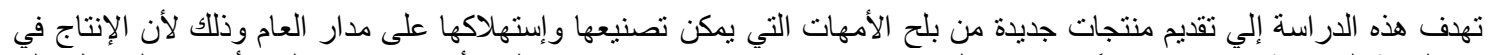

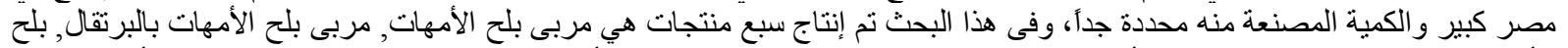

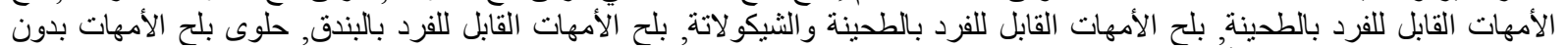

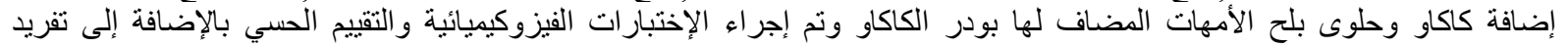

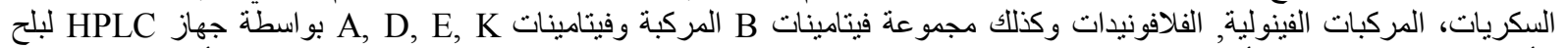

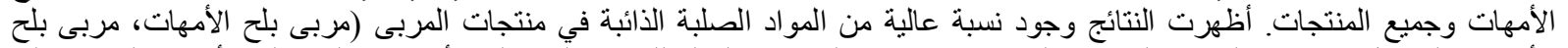

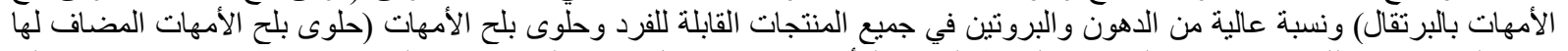

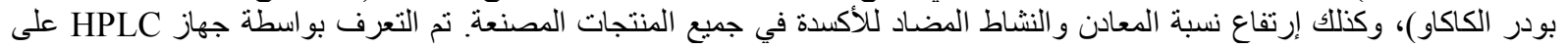

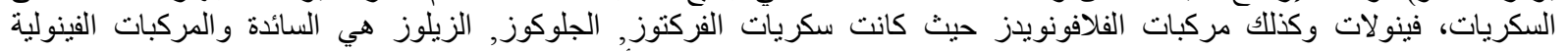

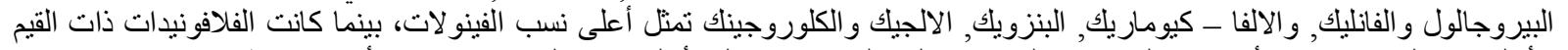

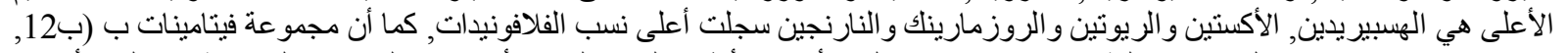

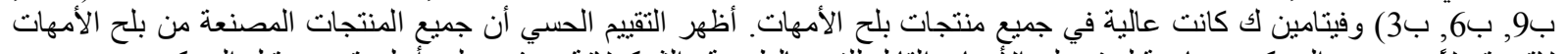
لاقت قبو لا من جميع المحكمين خاصة لمنتج بلح الأمهات القابل للفرد بالطحينة و الثشيكو لاتة حيث سجلت أعلى قيم من قبل المحكمين. 